\title{
Characterization of Hungarian Red Soils
}

\author{
${ }^{1}$ J. FEKETE; ${ }^{2} \mathrm{G}$. SZENDREI and ${ }^{1} \mathrm{M}$. CSIBI \\ ${ }^{1}$ Department of Soil Science and Agrochemistry, Szent István University, Gödöllő and \\ ${ }^{2}$ Department of Mineralogy and Petrology, Hungarian Natural History Museum, \\ Budapest
}

Red clays in Hungary are the products of soil forming processes occurring during the Tertiary period, not covered later by marine sediments. They were eroded under the climatic conditions of the Quaternary period, so at present they can only be found in sites protected against degradation, or where - due to their thickness and resistance - they could withstand the forces of erosion. Thus, red clays are fossil or relic products of soil formation. Their economic importance is far from negligible; vineyards, forests and arable cultivation can be found on them. Their influence may be detected in larger areas to where they have been washed away, settled and have mixed with other soils.

Different ideas have been formed on the distribution and characteristics of red clays and loamy products (KRETZOI, 1969; BIDLÓ, 1985; JÁNOSSY, 1979; JÁMBOR, 1980; BORSY \& SZÖÖR, 1979-1980; SCHWEITZER, 1993). STEFANOVITS (1963, 1967) found that the red clays of Hungary are genetically diverse.

Hungarian red clays differ greatly in their genesis and their physical and chemical characteristics from other soil types in the country, and also from red clays found elsewhere (FEKETE et al., 1997; FEKETE \& STEFANOVITS, 2002a,b). Red clays in Hungary are similar to the tropical and sub-tropical ferrallite soils (FEKETE, 1988 , 2002) regarding their formation and mineral characteristics. One of our aims is to explore the similarities in processes and characteristics, which would substantially help classification.

\section{Materials and Methods}

Samples were collected from nearly two hundred soil profiles from different parts of the North Hungarian Mountains and Transdanubian Mountains regions. 13 samples out of these were selected to represent the different types and sources of red clays (Table 1 ).

Correspondence to: JÓZSEF FEKETE, Szent István University, Department of Soil Science and Agrochemistry, H-2100 Gödöllő, Páter Károly u. 1. Hungary. E-mail: Fekete.Jozsef@mkk.szie.hu 
Table 1

Place of origin of the selected red clay samples

\begin{tabular}{|c|c|c|c|c|}
\hline & $\begin{array}{l}\text { of sample and } \\
\text { ace of origin }\end{array}$ & Depth in $\mathrm{cm}$ & \multicolumn{2}{|c|}{ Region } \\
\hline \multicolumn{5}{|c|}{ Red clays in Northern Hungary } \\
\hline 100. & Jósvafö & $20-55$ & $\begin{array}{c}\text { North Hungarian } \\
\text { Mountains }\end{array}$ & $\begin{array}{l}\text { Aggtelek Karst } \\
\text { (limestone) }\end{array}$ \\
\hline 108. & Mád & $40-60$ & \multirow{9}{*}{$\begin{array}{l}\text { Foreland of North- } \\
\text { Hungarian Mountains }\end{array}$} & $\begin{array}{l}\text { Tokaj Mountains } \\
\text { rhyolite tuff }\end{array}$ \\
\hline 222. & Salgótarján & $400-450$ & & $\begin{array}{c}\text { North-Hungarian } \\
\text { Basin }\end{array}$ \\
\hline 237. & Mátrakeresztes & $200-230$ & & \multirow{5}{*}{$\begin{array}{l}\text { Mátra Mountains } \\
\text { (volcanic rock } \\
237,210,236 \text { ) }\end{array}$} \\
\hline 210. & Gyöngyöstarján & $20-40$ & & \\
\hline 236. & Muzsla & $10-30$ & & \\
\hline 244. & Szurdokpüspöki & $350-380$ & & \\
\hline 35. & Hatvan & $50-67$ & & \\
\hline 152. & Valkó & $260-290$ & & \multirow{2}{*}{ Gödöllő Hills } \\
\hline 86. & Gödöllő & $30-60$ & & \\
\hline \multicolumn{5}{|c|}{ Red clays in Transdanubia } \\
\hline 119. & Szekszárd & $70-80$ & \multirow{3}{*}{ Transdanubian Hills } & \multirow{2}{*}{$\begin{array}{c}\text { Szekszárd Hills } \\
\text { (tertiary-quaternary } \\
\text { loam, clay }\end{array}$} \\
\hline 120. & Kakasd & $60-80$ & & \\
\hline 205. & Kővágószőlős & $8-15$ & & $\begin{array}{l}\text { Mecsek Mountains } \\
\text { (permian sandstone) }\end{array}$ \\
\hline
\end{tabular}

Analyses were carried out according to the methodology laid down in BUZÁS (1988, 1993). X-ray diffraction and (derivatographic) thermal analysis were applied to determine the mineral composition of the samples. Micromorphological studies were performed (SZENDREI, 2000). Thin sections were prepared by the method of diluted polyester resin impregnation. The micromorphological fetures were described according to BULLOCK et al. (1985).

\section{Analytical Results and Assessment}

\section{Basic soil analysis}

The soil texture varies between medium-heavy silt and heavy clay. The clay content is significantly high, although in red clays its dispersion is also high. The plasticity value $\left(\mathrm{K}_{\mathrm{A}}\right)$ is in accordance with the hygroscopicity value (hy $)_{1}$. The highest hygroscopicity values were detected in samples 100-Jósvafö, 210-Gyöngyöstarján, 35-Hatvan. 
Table 2

Basic soil analysis data of red clay samples

\begin{tabular}{|c|c|c|c|c|c|c|c|c|}
\hline \multirow{2}{*}{ No. } & \multirow{2}{*}{ Place of origin } & \multirow{2}{*}{$\begin{array}{c}\text { Depth } \\
(\mathrm{cm})\end{array}$} & \multirow{2}{*}{$\mathrm{K}_{\mathrm{A}}$} & \multirow{2}{*}{ hy $_{1}$} & \multicolumn{2}{|c|}{$\mathrm{pH}$} & \multirow{2}{*}{$\begin{array}{c}\mathrm{CaCO}_{3} \\
\% \\
\end{array}$} & \multirow{2}{*}{$\begin{array}{c}\text { Humus } \\
\%\end{array}$} \\
\hline & & & & & $\mathrm{KCl}$ & $\mathrm{H}_{2} \mathrm{O}$ & & \\
\hline \multicolumn{9}{|c|}{ Red clays in Northern Hungary } \\
\hline 100. & Jósvafő & $20-55$ & 62.00 & 9.72 & 4.74 & 5.92 & 0.00 & 0.19 \\
\hline 108. & Mád III & $40-60$ & 41.00 & 5.73 & 6.12 & 6.79 & 0.00 & 0.92 \\
\hline 222. & Salgótarján & $400-450$ & & & & & & \\
\hline 237. & Mátrakeresztes & $200-230$ & 68.00 & 7.50 & 5.28 & 6.69 & 0.00 & 2.60 \\
\hline 210. & Gyöngyöstarján & $20-40$ & & & & & & \\
\hline 236. & Muzsla & $10-30$ & 51.00 & 3.90 & 6.86 & 7.59 & 0.74 & 2.34 \\
\hline 244. & Szurdokpüspöki & $350-380$ & 53.00 & 2.80 & 3.77 & 5.12 & 0.00 & 0.32 \\
\hline 35. & Hatvan & $50-67$ & 96.00 & 9.42 & 7.38 & 8.38 & 0.45 & 0.12 \\
\hline 152. & Valkó & $260-290$ & 47.00 & 4.70 & 7.24 & 8.15 & 6.32 & 1.08 \\
\hline 86. & Gödöllö & $30-60$ & & & & & & \\
\hline \multicolumn{9}{|c|}{ Red clays in Transdanubia } \\
\hline 119. & Szekszárd & $70-80$ & 57.00 & 4.18 & 7.81 & 8.36 & 4.14 & 1.12 \\
\hline 120. & Kakasd & $60-80$ & 51.00 & 3.73 & 7.74 & 8.36 & 0.00 & 0.18 \\
\hline 205. & Kővágószőlős & $8-15$ & & & & & & \\
\hline
\end{tabular}

$\mathrm{K}_{\mathrm{A}}=$ upper limit of plasticity according to Arany; hy ${ }_{1}=$ hygroscopicity according to Kuron, modified by Sík

Chemical reaction $(\mathrm{pH})$ is slightly acidic, but some samples have neutral or alkaline chemical reaction, because they contain $\mathrm{CaCO}_{3}$. The humus content is generally low.

\section{Chemical analysis}

The data of total chemical analyses were considered important both for identifying the age of soils as well as for determining the weathering characteristics. The $\mathrm{SiO}_{2} / \mathrm{R}_{2} \mathrm{O}_{3}$ molecular ratio refers to the nature of weathering. From the total chemical analyses the $\mathrm{SiO}_{2}, \mathrm{Al}_{2} \mathrm{O}_{3}$ and $\mathrm{Fe}_{2} \mathrm{O}_{3}$ values are presented in percentage and their ratios for the clay fraction (Table 3 ).

Based on the molecular ratios the samples can be subdivided into the following genetic groups:

- In the 100-Jósvafö sample the weathering intensity is as strong as in tropical ferrallitic soils. This intensity is shown by the low $\mathrm{SiO}_{2} / \mathrm{R}_{2} \mathrm{O}_{3}$ ratio; this value is 1.74 in the clay fraction. Similar tropical weathering is indicated in samples 236Muzsla, 86-Gödöllö, 108-Mád, 119-Szekszárd and 120-Kakasd, where the $\mathrm{SiO}_{2} /$ $\mathrm{R}_{2} \mathrm{O}_{3}$ ratio of the clay fraction is around 2, or somewhat higher. The $\mathrm{Al}_{2} \mathrm{O}_{3} / \mathrm{Fe}_{2} \mathrm{O}_{3}$ ratio of these samples ranges between 3.1 and $4.9 \%$.

According to the mineralogical analysis of these samples (Table 4) the kaolinite content is significant, but montmorillonite can be found as well (236-Muzsla).

All above mentioned indicate slightly ferrallitic weathering. 


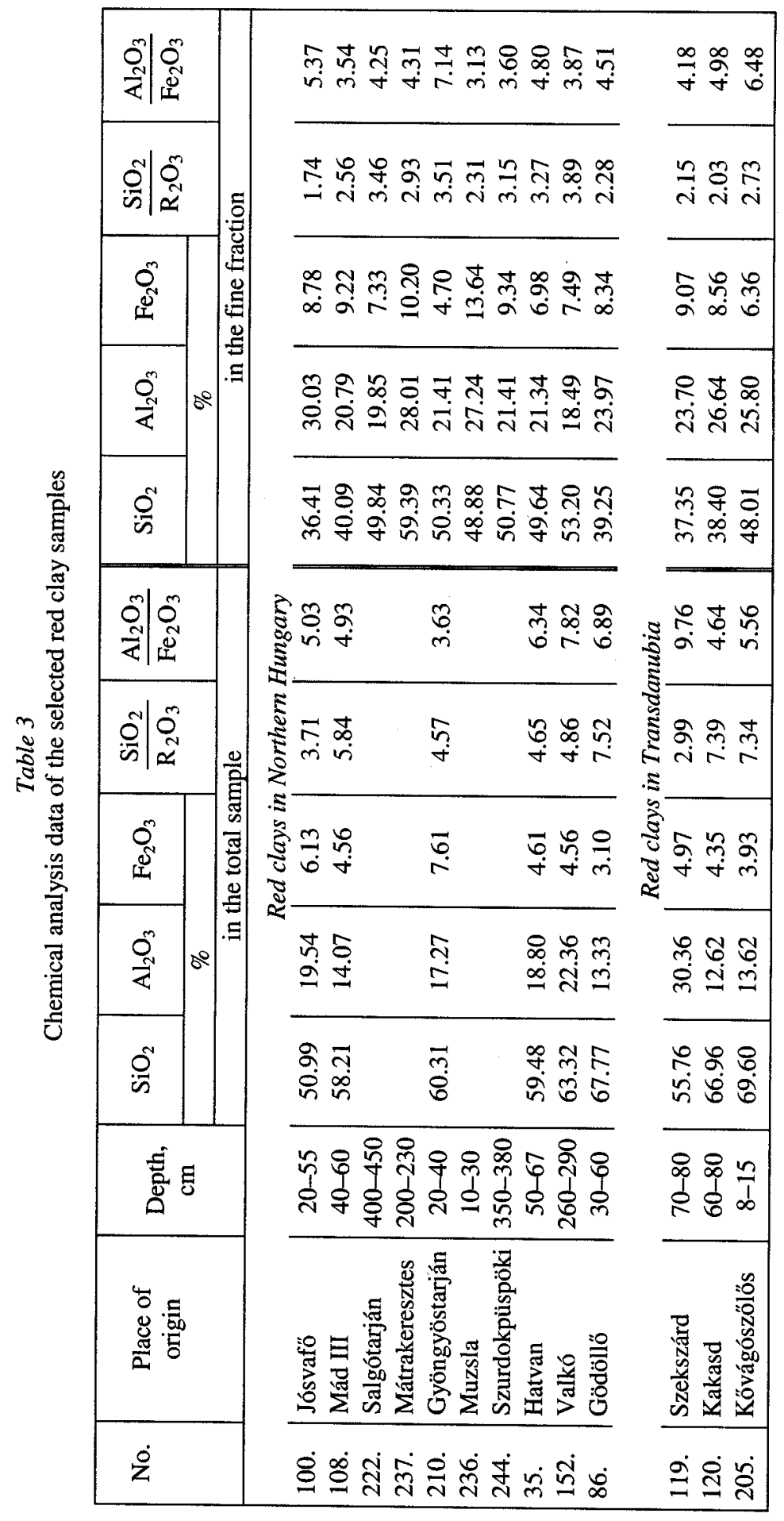




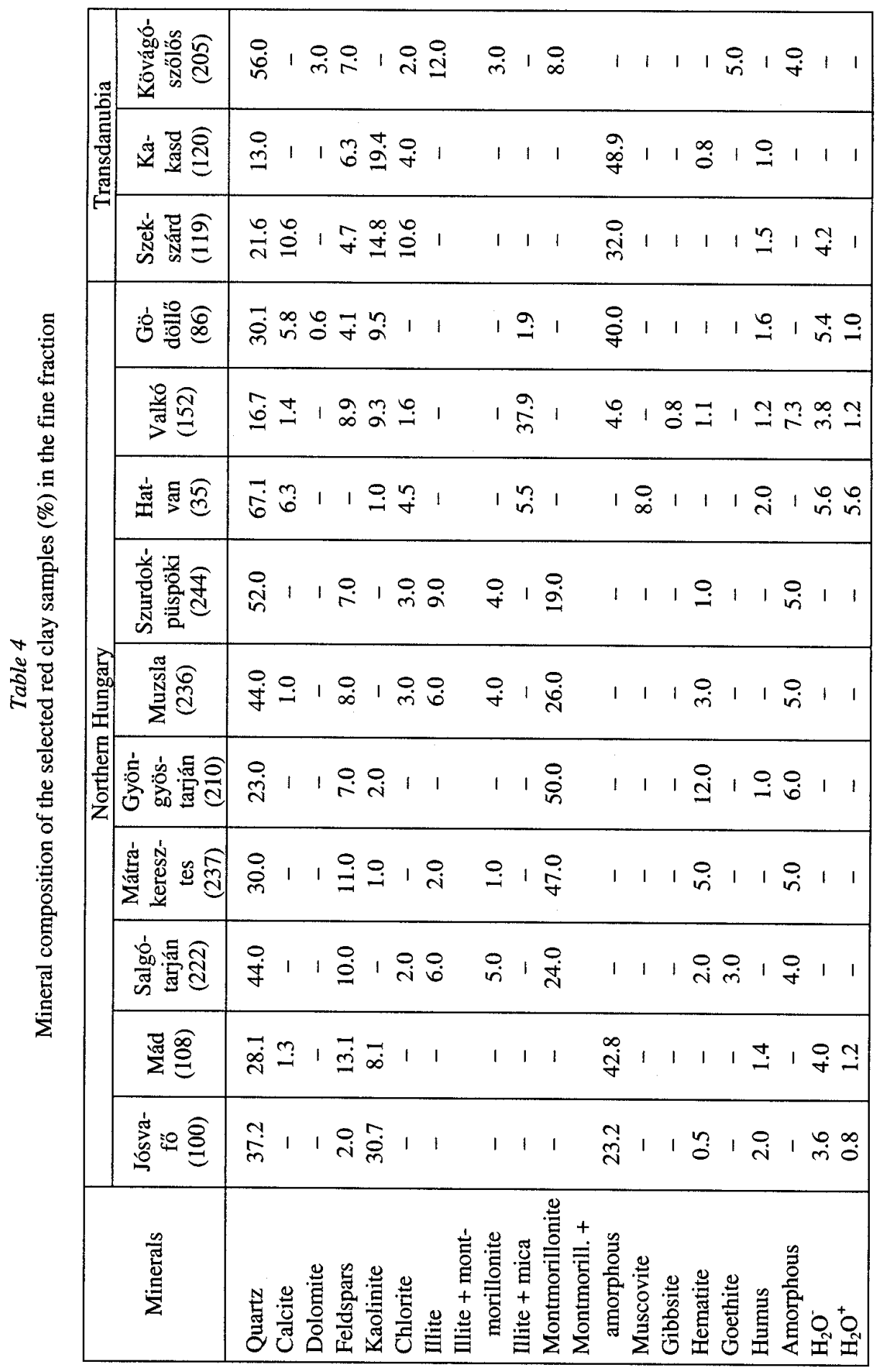


In conformity with the $\mathrm{Al}_{2} \mathrm{O}_{3} / \mathrm{Fe}_{2} \mathrm{O}_{3}$ ratio (5.37) the weathering is allitic (bauxitic) in the 100-Jósvafö sample. Tropical soil features like kaolinite and hematite contents can be found in it.

- In samples 222-Salgótarján, 237-Mátrakeresztes, 244-Szurdokpüspöki, 35Hatvan and 152-Valkó the weathering is siallitic, considering that the $\mathrm{SiO}_{2} / \mathrm{R}_{2} \mathrm{O}_{3}$ ratio falls in the 3-4 range. Their kaolinite content is very small, but montmorillonite (10-47) is significant. The above-mentioned samples are found in the Mátra Mountains, and in the Mátra Foothills, the foreland of the North-Hungarian Mountains region. These samples are red clays, but loess is also involved. In this case the resulted chemical composition shows siallitic weathering.

- In the 205-Kövágószőlős sample the weathering is siallitic, because the soil was formed on Permian sandstone.

It is likely that soils (red clays) with higher $\mathrm{SiO}_{2} / \mathrm{R}_{2} \mathrm{O}_{3}$ ratios are resultants of previous tectonic inversion and surface redeposition processes, and thus have a mixed composition of various weathering products (FEKETE \& STEFANOVITS, 2002a,b).

\section{Mineralogy}

The examination of the mineral composition by thermal analysis and X-ray diffraction is of decisive importance in identifying the age and weathering processes of red clays and also in assessing numerous characteristics of these clays.

On the basis of pedological and mineral analysis the red clays of Hungary can be ranked in various groups:

- Red soils formed on the Permian sandstone: Clay on the surface of Permian red sandstone does not contain kaolinite and hematite, but contains goethite (Sample: 205-Kövágószőlős).

- Red clays on Pannonian surface: In the Transdanubian Hills the red clays have been formed by weathering of the Pannonian surface. Illite, chlorite, montmorillonite and kaolinite can be found (Samples: 119-Szekszárd, 120-Kakasd).

- Red clays formed on rhyolite tuff: The red clays of the Tokaj Mountains, formed on rhyolite tuff with a low amount of kaolinite and $40 \%$ montmorillonite in the fine fraction (Sample: 108-Mád).

- Red soils of the Aggtelek Karst, Torna Hills: with 20-30\% montmorillonite and 30\% kaolinite content (Sample: 100-Jósvafö).

- The red clays in the Mátra Mountains and foothills: These samples have a significant quantity (20-50\%) of montmorillonite. It is characteristic of samples 222Salgótarján, 236-Muzsla and 244-Szurdokpüspöki that they contain little chlorite. There is no chlorite in samples 210-Gyöngyöstarján and 237-Mátrakeresztes. Low hematite contents $(1-12 \%)$ can be found in them.

- The red soils of the Northern periphery of the Hungarian Plain with significant amount of montmorillonite, and $10 \%$ to $20 \%$ kaolinite (Samples: 35 -Hatvan, 152 Valkó, 85-Gödöllő). 


\section{Micromorphology (Table 5)}

In the red clays of the Northern periphery of the Hungarian Plain micromorphological features of clay mobilization can be found in the groundmass (speckled, granostriated) in varying degrees as well as along the pores (coatings, hypocoatings and infillings) with different frequency (Samples: 35-Hatvan; 152-Valkó).

In the red clays of the Aggtelek Karst micromorphological features of clay mobilization were noted in the groundmass (speckled, granostriated, monostriated) and along the pores (coatings, hypocoatings and infillings) indicating stresses (Sample: 100-Jósvafö).

In the red clays of the foothills of the Tokaj Mountains: micromorphological features recognized are pronounced in the groundmass (speckled, granostriated, monostriated) and along the pores (coatings and infillings) indicating clay mobilization (Sample: 108-Mád).

Red clays formed by the weathering of the Pannonian surface: Speckled, granostriated and monostriated b-fabrics were only recognized. Clay coatings and infillings were absent probably due to the calcite content (Sample: 119-Szekszárd).

Table 5

Micromorphological features of clay components in the selected red clay samples

\begin{tabular}{|c|c|c|c|c|c|c|c|c|c|c|c|c|}
\hline \multirow{2}{*}{\multicolumn{2}{|c|}{ Sample }} & \multirow{2}{*}{\multicolumn{4}{|c|}{$\begin{array}{l}\mathrm{b}(\text { birefrangence })- \\
\text { fabric }\end{array}$}} & \multicolumn{7}{|c|}{ Pedological features } \\
\hline & & & & & & \multicolumn{7}{|c|}{ clay/ferruginous clay } \\
\hline$\dot{0}$ & Place of origin & 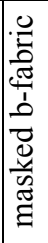 & 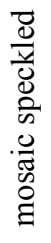 & 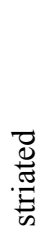 & 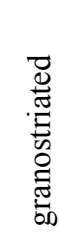 & 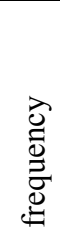 & $\begin{array}{l}0 \\
0 \\
0 \\
0 \\
0 \\
0 \\
0 \\
\Xi \\
0\end{array}$ & 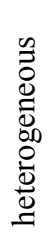 & 㤎 & $\begin{array}{l}\stackrel{\infty}{\Xi} \\
. \Xi \\
. \Xi\end{array}$ & 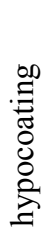 & $\begin{array}{l}\frac{0}{\Xi} \\
\text { 产 }\end{array}$ \\
\hline \multicolumn{13}{|c|}{ Red clays in Northern Hungary } \\
\hline 100. & Jósvafö & & $\mathrm{x}$ & $\mathrm{x}$ & $\mathrm{x}$ & $\mathrm{vc}$ & & & $\mathrm{x}$ & $\mathrm{x}$ & $\mathrm{x}$ & \\
\hline 108. & Mád & & $\mathrm{x}$ & $\mathrm{x}$ & $\mathrm{x}$ & $\mathrm{c}$ & $\mathrm{x}$ & & $\mathrm{x}$ & $\mathrm{x}$ & & $\mathrm{x}$ \\
\hline 222. & Salgótarján & & & & $(\mathrm{x})$ & $\mathrm{c}$ & & & $\mathrm{x}$ & $\mathrm{x}$ & & $\mathrm{x}$ \\
\hline 237. & Mátrakeresztes & & $\mathrm{x}$ & $\mathrm{x}$ & $\mathrm{x}$ & $\mathrm{vr}$ & & & & $\mathrm{x}$ & & \\
\hline 210. & Gyöngyöstarján & & & $\mathrm{x}$ & $\mathrm{x}$ & $\mathrm{vr}$ & $\mathrm{x}$ & & & $\mathrm{x}$ & & \\
\hline 236. & Muzsla & & $\mathrm{x}$ & $\mathrm{x}$ & $\mathrm{x}$ & $\mathrm{c}$ & $\mathrm{x}$ & & $\mathrm{x}$ & $\mathrm{x}$ & $\mathrm{x}$ & $\mathrm{x}$ \\
\hline 244. & Szurdokpüspöki & & $\mathrm{x}$ & $\mathrm{x}$ & $\mathrm{x}$ & vr & & & $\mathrm{x}$ & & $\mathrm{x}$ & $(\mathrm{x})$ \\
\hline 35. & Hatvan & & & & $(\mathrm{x})$ & $\mathrm{vc}$ & $\mathrm{x}$ & & $\mathrm{x}$ & $\mathrm{x}$ & & \\
\hline 152. & Valkó & & $\mathrm{x}$ & & $\mathrm{x}$ & $\mathrm{c}$ & $\mathrm{x}$ & & $\mathrm{x}$ & $\mathrm{x}$ & $\mathrm{x}$ & $\mathrm{x}$ \\
\hline 86. & Gödöllő & & & & $(\mathrm{x})$ & $\mathrm{vr}$ & & & $\mathrm{x}$ & $\mathrm{x}$ & & \\
\hline \multicolumn{13}{|c|}{ Red clays in Transdanubia } \\
\hline 119. & Szekszárd & & $\mathrm{x}$ & $\mathrm{x}$ & $\mathrm{x}$ & & & & & & & \\
\hline 120. & Kakasd & & $\mathrm{x}$ & $\mathrm{x}$ & $\mathrm{x}$ & & & & & & & \\
\hline 205. & Kővágőszőlős & & $\mathrm{x}$ & $\mathrm{x}$ & $\mathrm{x}$ & $\mathrm{vc}$ & & $\mathrm{x}$ & $\mathrm{x}$ & $\mathrm{x}$ & & \\
\hline
\end{tabular}

Remarks: vr: very rare, r: rare, c: common, vc: very common 
Red soils formed on Permian sandstone: Well marked micromorphological features indicating mobilization of clay particles in the groundmass (speckled, granostriated, monostriated) and along the pores (coatings and infillings) were observed (Sample: 205-Kővágószőlős).

The speckled and granostriated b-fabric of the groundmass, the occurrence of which is mainly due to swelling and shrinking, was observed in samples 86Gödöllö, 210-Gyöngyöstarján, 35-Hatvan:Gombos, 100-Jósvafö, 120-Kakasd, 205Kővágószőlős, 108-Mád, 237-Mátrakeresztes, 236-Muzsla, 222-Salgótarján, 119Szekszárd, 244-Szurdokpüspöki and 152-Valkó. Swelling was confirmed by the occurrence of stress coatings in the red clays from 100-Jósvafö and 244-Szurdokpüspöki.

Occurrence of clay coatings in samples 108-Mád, 236-Muzsla, 35-Hatvan: Gombos, 205-Kővágószőlős, 152-Valkó, 237-Mátrakeresztes, 222-Salgótarján, 244-Szurdokpüspöki and 86-Gödöllő were interpreted as micromorpholgical features of illuviation.

Illuviation coatings and infillings were taken notice of most often in samples 35Hatvan:Gombos and 205-Kővágószőlős.

\section{Summary}

Some pedological and micromorphological investigations were carried out on representative red clay samples selected from a large number of profiles. On the basis of conclusions drawn from the analytical results, the red clays can be divided into the following groups:

- The red clays of the foothills of the Tokaj Mountains were formed on rhyolite or rhyolite tuff, and are covered by loess in some areas. They are relic soils, older than loess, formed under the warm climate of the Tertiary Period. In addition to quartz they contain feldspars, illite, montmorillonite and a small amount of kaolinite.

- The red clays of Aggtelek Karst are Tertiary relic soils formed on Mesozoic limestone. The dominant clay mineral is kaolinite, but they contain a siginificant amount of smectite as well.

- The red clays of the Northern periphery of the Hungarian Plain are situated on clay, silt and sand layers of different origin or between loess depositions. They were formed in the Pliocene and at the turn of the Pliocene and Pleistocene. These soils have a medium clay content, with a large quantity of montmorillonite and a small amount of kaolinite.

- Red clays formed on Permian sandstones. These rocks were formed in the Permian period, and were issued from a mixture of sediments under tropical climate, tropical weathering. They are the signs of the oldest soil formation in Hungary. They can be characterized by their kaolinite, illite, montmorillonite and hematite contents.

- The red clays of the Transdanubian hilly region were formed by the weathering of the Pannonian surface between the end of the Miocene Period and the lower 
Pleistocene. Medium clay content is characteristic of these red clays. They contain kaolinite, montmorillonite, chlorite and a small amount of hematite.

Concerning micromorphological features, speckled and granostriated b-fabrics of the groundmass, mainly due to swelling and shrinking, were observed in some samples. Clay coatings are mainly interpreted as micromorphological features of illuviation.

The investigated red clays are similar to tropical and sub-tropical ferrallitic soils in respect of their formation and mineral characteristics.

The present research was supported by the National Scientific Research Fund (OTKA) under Grant No. T 043068.

Key words: red clay, relic, fossil, weathering, micromorphological features

\section{References}

BIDLÓ, G., 1985. Mineralogical investigation of middle Pliocene and Pliocene-Pleistocene transitional clays. In: Proc. $5^{\text {th }}$ Meeting of the European Clay Groups (Prague, 1983). 111-115.

BORSY, Z. \& SzÖÖR, G., 1979-1980. Comparative thermoanalytical and infrared spectroscopic analysis of the red soils at Tétel-halom and Dunaföldvár. (In Hungarian) Acta Geographica Debrecina. 18-19. 167-183.

Bullock, P. et al., 1985. Handbook for Soil Thin Section Description. Waine Research Publication. Wolverhampton.

BuZÁs, I. (Ed.), 1988. Manual of Soil and Agrochemical Analysis. II. (In Hungarian) Mezőgazda Kiadó. Budapest.

BuZÁs, I. (Ed.), 1993. Manual of Soil and Agrochemical Analysis. I. (In Hungarian) INDA 4231 Kiadó. Budapest.

FeKETE, J., 1988. Tropical Soils. (In Hungarian) Akadémiai Kiadó. Budapest.

FeKete, J., 2002. Physical and chemical features of red clays in Northern Hungary. Acta Geologica Hungarica. 45. (3) 231-246.

Fekete, J. \& Stefanovits, P., 2002a. Pedological features of red clays in Northern Hungary. Agrokémia és Talajtan. 51. 223-232.

Fekete, J. \& Stefanovits, P., 2002b. Physical and chemical properties of red clays in Transdanubia. (In Hungarian) Agrokémia és Talajtan. 51. 305-324.

Fekete, J., Stefanovits, P. \& Bidló, G., 1997. Comparative study of the mineral composition of red clays in Hungary. Acta Agron. Hung. 45. 427-441.

JÁMBOR, Á., 1980. Outlines of the stratigraphy of Pannonian formations. (In Hungarian) Általános Földtani Szemle. 14. 113-124.

JÁNossY, D., 1979. Subdivision of the Hungarian Pleistocene based on Vertebrate Faunas. (In Hungarian) Akadémiai Kiadó. Budapest.

KRETZOI, M., 1969. Sketch of the Late Cenozoic (Pliocene and Quaternary) terrestrial srtatigraphy of Hungary. (In Hungarian) Földrajzi Közlemények. 17. (3) 179-204. 
SchweItZer, F., 1993. Relief formation in the Pannonian Basin in the Neogene and in the early Quaternary Period. (In Hungarian) Doctoral Thesis. Hungarian Academy of Sciences. Budapest.

Stefanovits, P., 1963. Soils of Hungary. (In Hungarian) $2^{\text {nd }}$ ed. Akadémiai Kiadó. Budapest.

STEFANOVITS, P., 1967. Signs of Mediterranean soil formation in Hungary. (In Hungarian) Bulletin of the University of Agricultural Sciences. 227-235.

SzENDREI, G., 2000. Micromorphology of Soils. (In Hungarian) ELTE-Eötvös Kiadó. Budapest. 